\title{
Subsolidus Solution and Oxide Ionic Conductivity of Nd-substituted Bismuth Yttria Fluorites
}

(Larutan Subpepejal dan Kekonduksian Ion Oksida bagi Fluorit Bismuth Yittria yang Digantikan dengan Nd)

\author{
N. RAHMAN, K.B. TAN*,Z.ZAINAL,C.C. KHAW \& M.P. CHON
}

\begin{abstract}
Pure phase $\mathrm{Bi}_{1.6} \mathrm{Y}_{0.4-\mathrm{x}} \mathrm{Nd}_{x} \mathrm{O}_{3}$ solid solution with $\mathrm{x}=0.00,0.10$ and 0.20 was successfully synthesised via conventional solid state method at $850^{\circ} \mathrm{C}$ in $21 \mathrm{~h}$. The materials were refined and fully indexed with space group Fm-3m and lattice parameters, a ranging from 5.5124(1) A to 5.5289(4) $\AA$. Variation of the lattice parameters of these materials were found in an almost linear correlation with increasing $\mathrm{Nd}_{2} \mathrm{O}_{3}$ dopant concentration. Thermal analysis of $\mathrm{Bi}_{1.6} \mathrm{Y}_{0.4-x} \mathrm{Nd}_{x} \mathrm{O}_{3} \mathrm{solid}$ solution showed no thermal event that associated with any phase transition or weight loss within the studied temperature range of 35 to $900^{\circ} \mathrm{C}$. The electrical properties of the samples were investigated by ac impedance analyser, HP4192 at temperature ranging from 25 to $800^{\circ} \mathrm{C}$ over frequency of $5 \mathrm{~Hz}$ to $13 \mathrm{MHz} . \mathrm{Bi}{ }_{1.6} \mathrm{Y}_{0.3} \mathrm{Nd}_{0.1} \mathrm{O}_{3}$ exhibited the highest oxide ion conductivity among the synthesised samples in $\mathrm{Bi}_{1.6} \mathrm{Y}_{0.4-x} \mathrm{Nd}_{x} \mathrm{O}_{3}$ solid solution.
\end{abstract}

Keywords: Fluorite; oxide ion conductivity; solid Solution; $x$-ray diffraction

\section{ABSTRAK}

Larutan subpepejal Bi ${ }_{1.6} Y_{0.4-x} \mathrm{Nd}_{x} \mathrm{O}_{3}$ berfasa tulen dengan $\mathrm{x}=0.00$, 0.10 dan 0.20 telah berjaya dihasilkan melalui kaedah keadaan pepejal pada suhu $850^{\circ} \mathrm{C}$ dalam tempoh 21 jam. Bahan-bahan berkenaan telah dihalusi dan diindeks sepenuhnya dengan kumpulan ruangan Fm-3m dengan nilai parameter kekisi dalam lingkungan 5.5124(1) A hingga 5.5289(4) A. Parameter kekisi bahan-bahan berkenaan menunjukkan kolerasi yang berkadar terus dengan penambahan $\mathrm{Nd}_{2} \mathrm{O}_{3}$ yang didopkan. Analisis terma bagi larutan pepejal $\mathrm{Bi}_{1.6} \mathrm{Y}_{0.4-x} \mathrm{Nd}_{x} \mathrm{O}_{3}$ tidak menunjukkan sebarang acara terma yang berkaitan dengan peralihan fasa atau penurunan berat dalam suhu kajian dari 35 hingga $900^{\circ} \mathrm{C}$. Sifat elektrik dicirikan pada suhu $\sim 30$ hingga $800^{\circ} \mathrm{C}$ dengan menggunakan penganalisis AC impedans, HP4192 dalam julat frekunsi daripada $5 \mathrm{~Hz}$ hingga $13 \mathrm{MHz}$. Bi ${ }_{1.6} \mathrm{Y}_{0.3} \mathrm{Nd}_{0.1} \mathrm{O}_{3}$ mempunyai kekonduksian ion oksida yang paling tinggi antara fasa tulen yang dihasilkan dalam sistem larutan pepejal $\mathrm{Bi}_{1.6} \mathrm{Y}_{0.4-x} \mathrm{Nd}_{x} \mathrm{O}_{3}$.

Kata kunci: Fluolit; kekonduksian oksida; larutan pepejal; pembelauan sinar-x

\section{INTRODUCTION}

Advanced materials for energy related applications have been identified as the key research subject as a consequence of depleting renewable energy source. The structural flexibility and composition stoichiometry of oxide materials from binary and/or higher systems has yielded exploitable properties that could satisfy the needs for alternative energy. To date, a comprehensive literature on various bismuth based binary phases is available of which extensive works covering their electrical properties and possible applications in solid electrolyte fuel cell (SOFC), ionic conductor and sensor are disclosed (Boivin 2001; Boivin \& Mairesse 1998; Stambouli \& Traversa 2002; Yashima \& Ishimura 2003).

Despite the behaviors of being filthy and volatile, bismuth oxide has been considered in the realm of much research as it gives rise to many interesting properties. At room temperature, the structure of $\mathrm{Bi}_{2} \mathrm{O}_{3}$ is predominantly a monoclinic phase that transforms into $\delta$-phase, a face centered cubic (fcc) at transition temperature of $\sim 730^{\circ} \mathrm{C}$ before reaching its melting point of $825^{\circ} \mathrm{C}$ (Harwig \&
Gerads 1978; Sammes et al. 1999). Two meta-stable intermediates, tetragonal- $\beta$ phase and body centered cubic(bcc) g-phase formed upon cooling may have attracted less attention due to their relatively lower ionic conductivity within these polymorphs (Harwig \& Gerads 1979). On the other hand, the high ionic conductivity of $\delta$-phase has captured great attention as a potential candidate to replace the commercial yttiria stablised zirconia (YSZ) as solid electrolyte in fuel cell application (Kruidhof et al. 1990). However, the feasibility of using $\delta$-phase requires immediate solutions especially to tackle the problems of its stability and atmospheric sensitivity.

In attempts to bring down the high temperature $\delta$-phase, various dopants have been introduced that accounted for the $\mathrm{Bi}_{2} \mathrm{O}_{3}-\mathrm{M}_{2} \mathrm{O}_{3}(\mathrm{M}=\mathrm{Y}, \mathrm{Er}, \mathrm{Gd}, \mathrm{La}$, Dy and other rare earth elements) systems (Sammes et al. 1999; Takahashi \& Iwahara 1978; Watanabe \& Kikuchi 1986). It is perceived that ionic radii of the introduced dopants could have a great impact on the structure in which relative larger cation would promote formation of the rhombohedral phase instead of the desirable $\delta$-phase. By far, the high 
temperature modification of $\mathrm{Bi}_{2} \mathrm{O}_{3}$ or sometimes referred as $\delta *$ has been successfully synthesised through substitution of 25 mol\% $\mathrm{Y}_{2} \mathrm{O}_{3}$ (Watanabe \& Kikuchi 1986). Despite controversial descriptions and uncertainties over the phase equilibrium studies in $\mathrm{Bi}_{2} \mathrm{O}_{3}-\mathrm{Y}_{2} \mathrm{O}_{3}$ binary system, several numbers of phases are reported to have formed over a broad range of compositions. The authors also suggested that the fluorite-structured $\delta$-phase was somewhat stabilised by increasing $\mathrm{Y}^{3+}$ concentration as this helped to achieve oxygen vacancy ordering on the sub-lattice in chains along the $<111>$ and $<110>$ directions (Sammes et al. 1999; Takahashi et al. 1975; Watanabe 1996). On the other hand, high ionic conductivity of these phases was postulated to be a result of several criteria: Defective structure that could accommodate up to $25 \mathrm{~mol} \%$ of oxygen vacancy; highly polarisable $\mathrm{Bi} 6 \mathrm{~s}^{2}$ lone pair electrons that facilitated oxide ion mobility; and great Bi tolerance towards highly disordered surroundings (Mairesse 1993). A recent study showed that $\left(\mathrm{Bi}_{2} \mathrm{O}_{3}\right)_{1-\mathrm{x}}\left(\mathrm{Y}_{2} \mathrm{O}_{3}\right)_{\mathrm{x}}$ solid solution with $\mathrm{x}=0.15$, $0.20,0.30$ and 0.40 had comparable or better performance of oxide ionic conductivity in relation to the yttria stabilised zirconia solid electrolyte (Tan et al. 2012).

Consider the close similarity of chemical properties and ionic size, neodymium has been selected as a dopant in an attempt to enhance the electrical properties of materials in bismuth yttria binary system. In this paper, we will discuss our findings on the subsolidus solution formation and electrical properties of $\mathrm{Nd}$ substituted bismuth yttria fluorites.

\section{EXPERIMENTAL DETAILS}

Reagent grade oxides, $\mathrm{Bi}_{2} \mathrm{O}_{3}\left(99 \%\right.$, Aldrich), $\mathrm{Y}_{2} \mathrm{O}_{3}$ (99\%, Aldrich) and $\mathrm{Nd}_{2} \mathrm{O}_{3}$ (99\%, Sigma) were used as the starting materials for samples synthesis of general formula, $\mathrm{Bi}_{1.6} \mathrm{Y}_{0.4-\mathrm{x}} \mathrm{Nd}_{\mathrm{x}} \mathrm{O}_{3}(0 \leq \mathrm{x} \leq 0.4)$. Oxides were treated at different pre-firing temperatures prior to weighing and further solid state reaction. Stoichiometric amount of oxides were weighed out, ground homogeneously with sufficient acetone and then transferred into alumina boat before step-wise heat treatment. The mixtures were allowed to react at initial temperatures of 300 and $800^{\circ} \mathrm{C}$ for every $2 \mathrm{~h}$; whilst, the firing condition was finalised at $850^{\circ} \mathrm{C}$ over $21 \mathrm{~h}$ in muffle furnace. Intermediate regarding was performed in order to refresh surface area for better reactivity. Phase purities of the prepared samples were investigated by Shidmazu x-ray powder diffractometer (XRD) 6000, which was equipped with a diffracted beam graphite monochromator, $\mathrm{CuK} \alpha$ radiation, $1.5418 \AA$ A a $\mathrm{a}$ routine scan rate of $2 \% \mathrm{~min}$. Lattice parameter refinement was performed using Chekcell software using XRD data that collected at slow scan rate of $0.1 \% \mathrm{~min}$. The thermal stability of the phase pure samples was examined by Perkin Elmer thermal gravimetry analyser (TGA 7). On the other hand, pelletised sample of diameter, $\sim 8 \mathrm{~mm}$ and thickness, 1 $2 \mathrm{~mm}$ was coated with gold electrodes and then attached firmly to a conductivity jig. The electrical properties of the samples were characterised using HP 4192A impedance spectroscopy analyser over a frequency range of $5 \mathrm{~Hz}-$ $13 \mathrm{MHz}$. The measurements were performed in heat-cool cycle ranging from room temperature, $\sim 30$ to $800^{\circ} \mathrm{C}$ with incremental steps of $50^{\circ} \mathrm{C}$ and equilibration time of $25 \mathrm{~min}$.

\section{RESULTS AND DISCUSSION}

The samples with a general formula $\mathrm{Bi}_{1.6} \mathrm{Y}_{0.4-\mathrm{x}} \mathrm{Nd}_{\mathrm{x}} \mathrm{O}_{3}$ $(0.0 \leq x \leq 0.40)$ are synthesised via solid state reaction and their phase purities were analysed using qualitative $\mathrm{X}$-ray diffraction analysis. The formation of single phase samples is confirmed by the absence of extra peaks that usually corresponds to unreacted constituent oxides or other binary phases. X-ray diffraction (XRD) patterns of phase pure samples with composition, $0.0 \leq \times \leq 0.20$ are fully indexed as illustrated in Figure 1. These materials are crystallised in face centered cubic, space group Fm$3 \mathrm{~m}$ with lattice parameters, $a$ ranging from 5.5124(1) $\AA$ to 5.5289(4) A. Meanwhile, characteristic diffraction peaks of secondary phases, e.g. $\mathrm{BiNdO}_{3}$ binary phase (ICDD card number: 89-4390) and excessive $\mathrm{Nd}_{2} \mathrm{O}_{3}$ (ICDD card number: 21-0579) are discernible as value $\mathrm{x}$ increases. In order to eliminate these phases, further heat treatment for a prolonged duration and/or higher firing temperatures are performed and yet, these attempts are not successful.

Note that a substitutional solid solution system will have atom or ion that is being introduced replaces directly

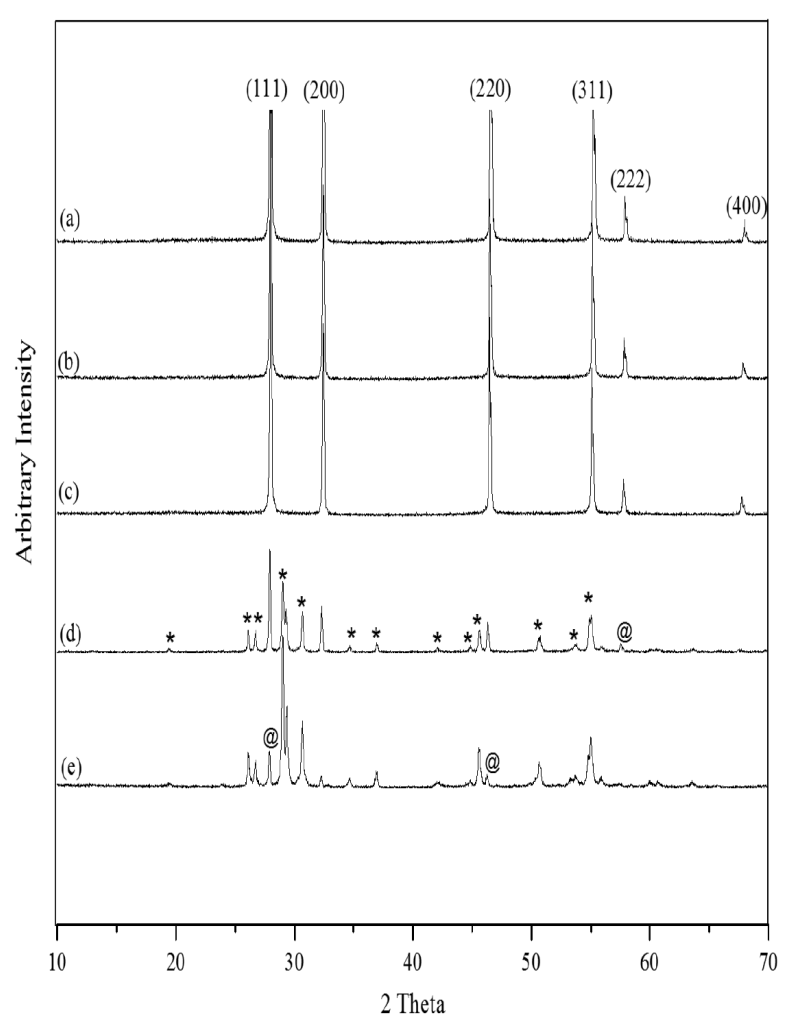

FIGURE 1. XRD patterns of (a) $\mathrm{Bi}_{1.6} \mathrm{Y}_{0.4} \mathrm{O}_{3}$ (b) $\mathrm{Bi}_{1.6} \mathrm{Y}_{0.3} \mathrm{Nd}_{0.1} \mathrm{O}_{3}$ (c) $\mathrm{Bi}_{16} \mathrm{Y}_{02} \mathrm{Nd}_{02} \mathrm{O}_{3}$ (d) $\mathrm{Bi}_{16} \mathrm{Y}_{01} \mathrm{Nd}_{03} \mathrm{O}_{3}$ (e) $\mathrm{Bi}_{16} \mathrm{Nd}_{04} \mathrm{O}_{3}$ prepared via conventional solid state method at $850^{\circ} \mathrm{C}$. (*= $\left.\mathrm{BiNdO}_{3}, @=\mathrm{Nd}_{2} \mathrm{O}_{3}\right)$ 
an atom or ion of the same charge in the parent structure (West 1999). For cationic replacement of this system, the solid solution meets a few criteria of which trivalent $\mathrm{Nd}^{3+}$ ions has similar charge to that of $\mathrm{Y}^{3+}$ cation. This suggests that structural changes involving interstitials or vacancies will not be required as to maintain electroneutrality. Secondly, ionic radius of $0.90 \AA$ A for $\mathrm{Y}^{3+}$ is approximately $0.08 \AA$ Á smaller than that of $\mathrm{Nd}^{3+}$ yielding cationic radii difference of less than $15 \%$ (Shannon 1976). Finally, the formation of $\mathrm{Nd}$ substituted solid solution is expected to be thermodynamically stable. For thermal equilibrium condition, the firing duration required to synthesise single phase $\mathrm{Bi}_{1.6} \mathrm{Y}_{0.4-\mathrm{x}} \mathrm{Nd}_{\mathrm{x}} \mathrm{O}_{3}$ solid solution is finalised as $21 \mathrm{~h}$ and that, no further changes should be observed. On the other hand, the color of the samples is observed to change gradually from yellowish to greenish as the concentration of $\mathrm{Nd}_{2} \mathrm{O}_{3}$ increases.

The lattice parameters of $\mathrm{Bi}_{1.6} \mathrm{Y}_{0.4-x} \mathrm{Nd}_{\mathrm{x}} \mathrm{O}_{3}$ solid solution $(0.00 \leq x \leq 0.20)$ are obtained from structural refinement using Chekcell program. It is observed that the lattice parameters increase gradually with increasing concentration of $\mathrm{Nd}_{2} \mathrm{O}_{3}$ (Figure 2). If the structural variation of a solid solution is governed solely by size factor, the cell parameters and densities that in accordance with Vegard's law should be directly proportional to the atomic percentage of solute. This means that the solid solution formation can be ascertained if the prepared samples have a linear correlation between lattice parameters and compositions. The slight expansion in unit cell, i.e. larger lattice parameters with higher amount of $\mathrm{Nd}_{2} \mathrm{O}_{3}$ could be attributed to relatively larger $\mathrm{Nd}^{3+}$ cation radius. The bond length of $\mathrm{Nd}-\mathrm{O}$ is thus expected to be longer than $\mathrm{Y}-\mathrm{O}$ and cause the expansion of cell parameters.

The thermal stability of $\mathrm{Bi}_{1.6} \mathrm{Y}_{0.4-\mathrm{x}} \mathrm{Nd}_{\mathrm{x}} \mathrm{O}_{3}$ solid solution is investigated by TGA in the temperature range of 50 to $800^{\circ} \mathrm{C}$ with a heating rate of $10^{\circ} \mathrm{C} / \mathrm{min}$. Horizontal lines across the heating temperature range are observed in Figure 3 , indicating that there is no significant weight change occurred when the samples are heated up to $800^{\circ} \mathrm{C}$. However, a small variation of weight change could be resulted from the samples' hygroscopic behaviour. $\mathrm{Nd}$ substituted samples are considered thermally stable and impervious to any thermal event within the studied temperature range. Meanwhile, $\mathrm{Bi}_{1.6} \mathrm{Y}_{0.4-\mathrm{x}} \mathrm{Nd}_{\mathrm{x}} \mathrm{O}_{3}(0.00 \leq$ $\mathrm{X} \leq 0.20)$ samples appeared to have isotropic surface and porous as shown in their SEM micrographs (Figure 4). The grain sizes are fall within a range of $\sim 4-26 \mu \mathrm{m}$ of which larger grain contains hundreds of smaller crystallites.

The electrical response of phase pure samples has been carefully studied using ac impedance analyser over a broad range of temperature frequencies. The electrical data are corrected for samples' geometry factor (area/thickness; $\mathrm{cm}^{-1}$ ) and stray capacitance of an open jig. For an ideal Debye response of ionic conducting materials, perfect semicircle of an equivalent electrical circuit of parallel RC elements should be observed in complex Cole-Cole plot. Conductivity values of these materials at various temperatures are deduced from high intercept of complex plane plots, i.e. Z" equals to zero in a complex impedance formalism, $Z^{*}=Z^{\prime}-\mathrm{jZ}$ " where Z' and Z' represent

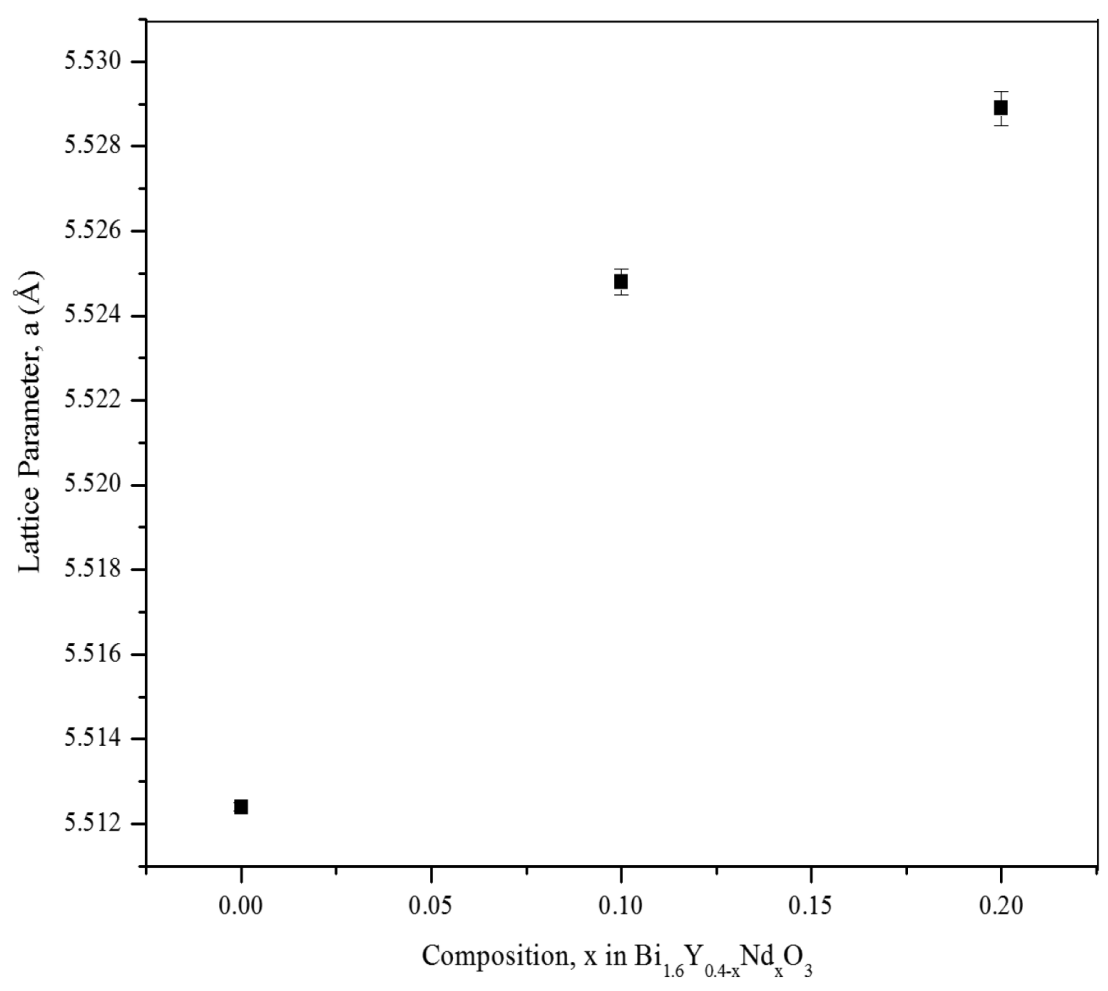

FIGURE 2. Lattice parameter, $a$ as a function of composition, $\mathrm{x}$ in $\mathrm{Bi}_{1.6} \mathrm{Y}_{0.4-\mathrm{x}} \mathrm{Nd}_{\mathrm{x}} \mathrm{O}_{3}$ solid solution $(0.00 \leq x \leq 0.20)$ 


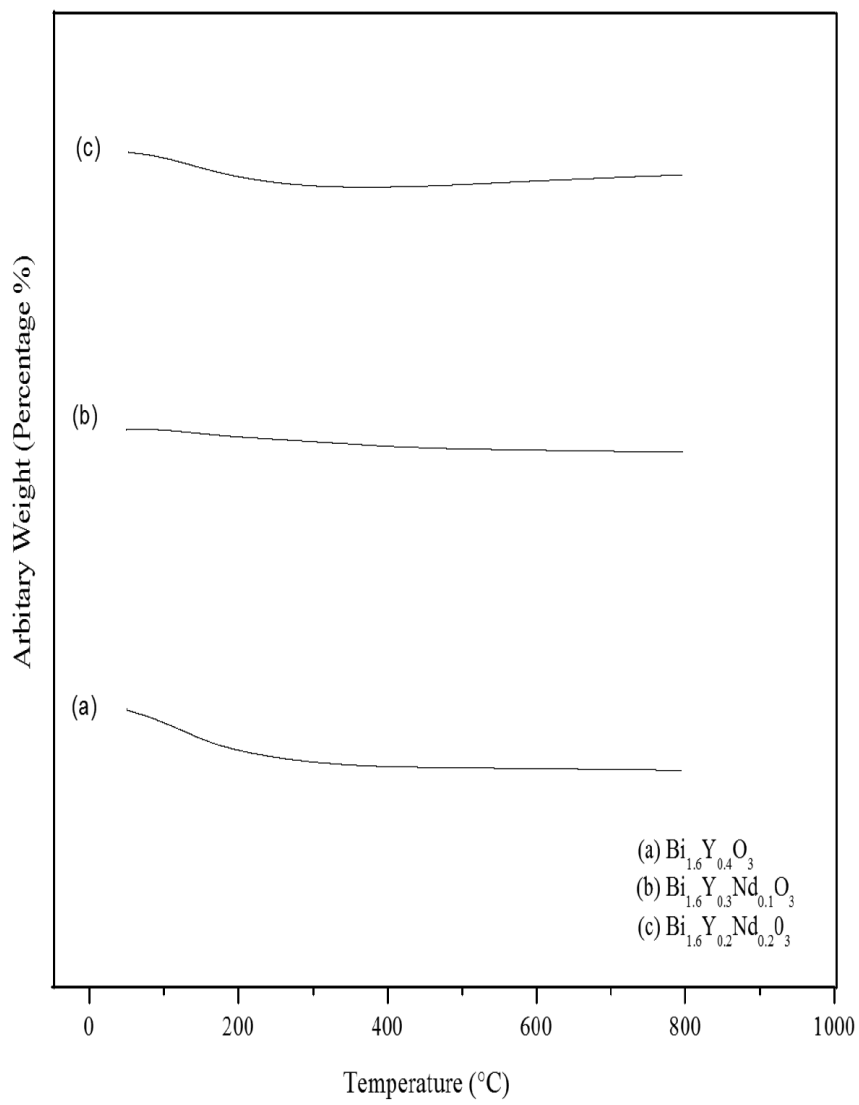

FIGURE 3. TGA thermograms of $\mathrm{Bi}_{16} \mathrm{Y}_{04-\mathrm{x}} \mathrm{Nd}_{\mathrm{x}} \mathrm{O}_{3}$ solid solution prepared via solid state method at $850^{\circ} \mathrm{C}$. (a) $\mathrm{x}=0.0$ (b) $\mathrm{x}=0.1$ (c) $\mathrm{x}=0.2$
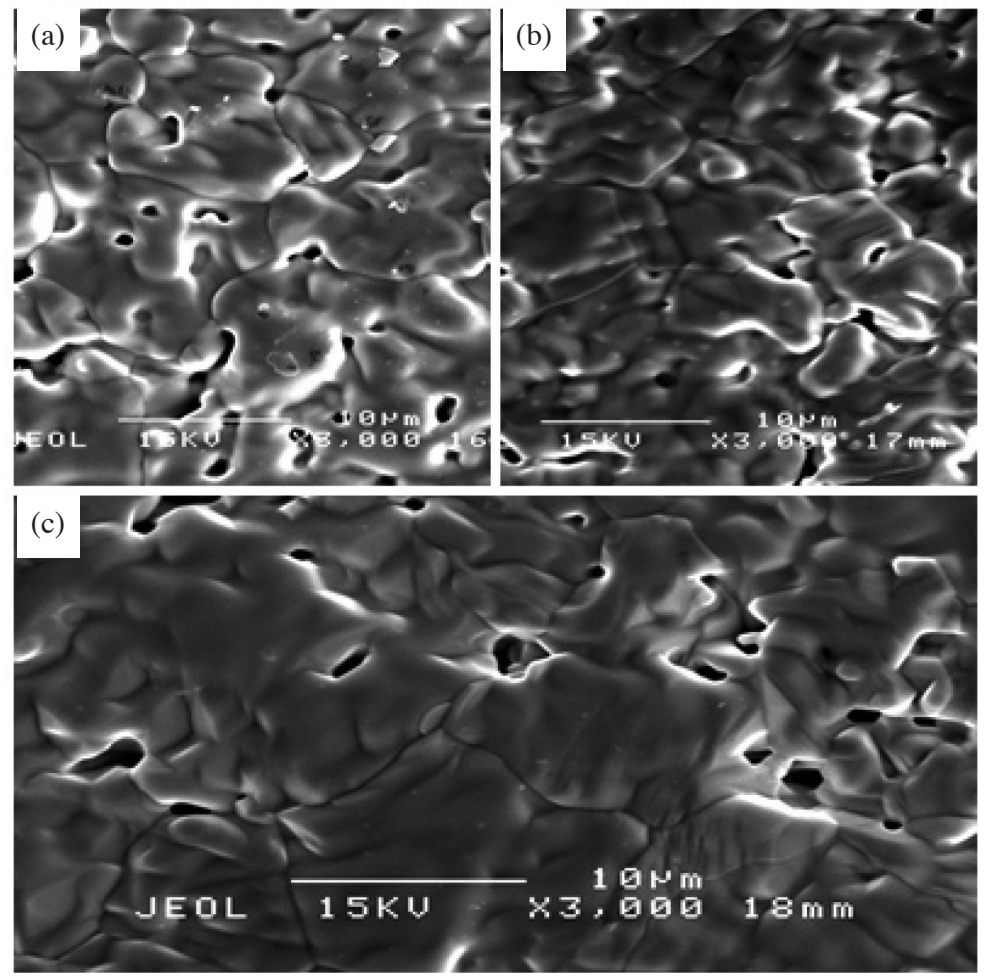

FIGURE 4. Recorded SEM micrographs of $\mathrm{Bi}_{1.6} \mathrm{Y}_{0.4-\mathrm{x}} \mathrm{Nd}_{\mathrm{x}} \mathrm{O}_{3}$ at magnification of 3000x. (a) $\mathrm{x}=0.0$ (b) $\mathrm{x}=0.1$ (c) $\mathrm{x}=0.2$ 
the real and imaginary part of impedance component (Sinclair \& West 1989). The plots of these materials at low temperatures, typically $250^{\circ} \mathrm{C}$ and/or higher show perfect semicircle at high frequency which corresponding to the bulk response (Figure 5). The semicircle becomes smaller and shifts toward lower impedance, Z' values, indicating that smaller bulk resistivity of the materials. As temperature increases, charge carriers are expected to have greater thermal energy, better mobility and / or higher defect concentration that could facilitate the conduction mechanism.

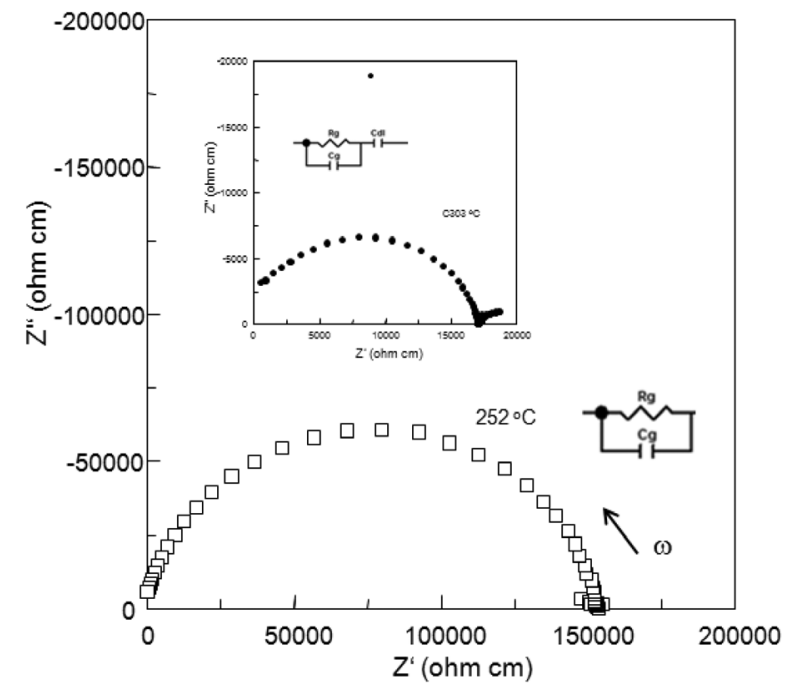

FIGURE 5. Complex Cole-Cole plot of $\mathrm{Bi}_{1.6} \mathrm{Y}_{0.3} \mathrm{Nd}_{0.1} \mathrm{O}_{3}$ at $252^{\circ} \mathrm{C}$ and spike of oxide ionic conductivity behavior at $303^{\circ} \mathrm{C}$ as shown in the inset of figure

For $\mathrm{Bi}_{1.6} \mathrm{Y}_{0.3} \mathrm{Nd}_{0.1} \mathrm{O}_{3}$, a perfect semicircle is observed at temperature of $252^{\circ} \mathrm{C}$ and then followed by a spike in the lower frequency region that associated with blocking electrode effects at elevated temperatures (inset of Figure $5)$. The associated capacitance value of $6.17 \times 10^{-12} \mathrm{~F} \mathrm{~cm}^{-1}$ calculated from $\omega_{\max } \mathrm{RC}=1$ (Figure 5) is in addition providing further evidence for the bulk response which proposed earlier (Irvine et al. 1990; Khaw et al. 2009). At temperature $303^{\circ} \mathrm{C}$, high frequency semicircle has an associated capacitance $6.33 \times 10^{-12} \mathrm{~F} \mathrm{~cm}^{-1}$ and a spike with an associated capacitance in order of $\sim 10^{-9}$ that caused by the formation of electrode double layer capacitance, $\mathrm{C}_{\mathrm{dl}}$ at electrode electrolyte interface (Sinclair \& West 1989). It is a characteristic of ionic conducting solids with blocking electrodes. The $45^{\circ}$ of spike with Z' axis obtained indicates that the electrode electrolyte interface is not fully blocked by the ions. Oxide ions, $\mathrm{O}^{2-}$ are the corresponding charge carrier and the electrode electrolyte interface is semiblocked by the air gap formed by the reduction of $\mathrm{O}^{2-}$ within the structure. The spike becomes more predominant arising from the occurrence of polarisation phenomena at the blocking electrodes and diffusion limited Warburg impedance. Hence, these spikes provide clear evidence that electrical conduction of $\mathrm{Bi}_{1.6} \mathrm{Y}_{0.4-\mathrm{x}} \mathrm{Nd}_{\mathrm{x}} \mathrm{O}_{3}(0.00 \leq \mathrm{x} \leq 0.20)$ samples is attributed to highly mobile oxide ions (Irvine et al. 1990; Sammes et al. 1999; Tan et al. 2012).

For an ideal Debye response representing homogenous bulk properties, maxima of electric modulus, M" and the imaginary part of real impedance, Z" against logarithmic frequency function must be coincident. The value of full width at half maximum (FWHM) of M" should be 1.14 decades for an electrically homogeneous materials. A slight deviation between Z" and M" maxima is discernible (Figure 6) and the magnitude of 1.7 decades from FWHM of M" suggests possible contribution from other electroactive region (Sinclair \& West 1989).

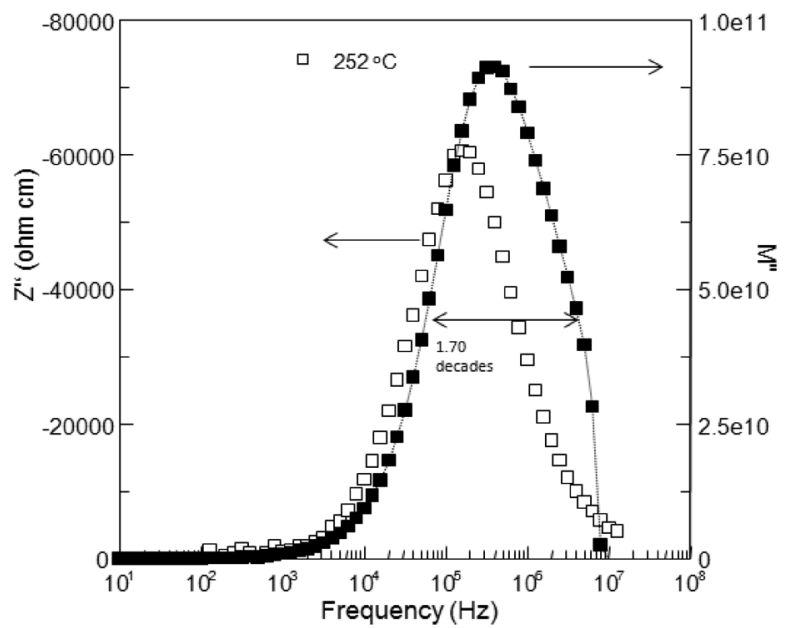

FIGURE 6. Combined Z" and M" spectroscopic plot of $\mathrm{Bi}_{1.6} \mathrm{Y}_{0.3} \mathrm{Nd}_{0.1} \mathrm{O}_{3}$ at $252^{\circ} \mathrm{C}$

Note that the reciprocal form of complex impedance will yield complex admittance formalism, $\mathrm{Y}^{*}=\left(\mathrm{Z}^{*}\right)^{-1}$ of which both real and imaginary components of admittance are correlated by a formula, $\mathrm{Y}^{*}=\mathrm{Y}^{\prime}=\mathrm{j} \mathrm{Y}^{\prime}$. The temperature dependence of ac conductivity of $\mathrm{Bi}_{1.6} \mathrm{Y}_{0.4-\mathrm{x}} \mathrm{Nd}_{\mathrm{x}} \mathrm{O}_{3}(0.00 \leq \mathrm{x}$ $\leq 0.20$ ) samples is found to increase gradually at elevated temperatures. The thermally activated conduction process conforms well to the Arrhenius conductivity type, $\sigma=$ $\sigma_{\mathrm{o}} \exp \left(-\mathrm{Ea} / \mathrm{k}_{\mathrm{B}} \mathrm{T}\right)$ where $\sigma_{\mathrm{o}}$ is the conductivity at infinite temperature, whilst $\mathrm{T}, \mathrm{k}_{\mathrm{B}}$ and $\mathrm{Ea}$ are, respectively, absolute temperature, Boltzmann's constant and activation energy for conduction. On the other hand, conductivity data of the pellets with normalised dimension are extracted from the plateau regime that found in the curves of frequencyindependent $\mathrm{Y}^{\prime}$. The values obtained at fixed frequency of $10 \mathrm{kHz}$ for different temperatures are illustrated in Figure 7 of which composition with $\mathrm{x}=0.1$ exhibits the highest conductivity with an apparent activation energy of $0.94 \mathrm{eV}$. However, a dip in conductivity is discernable for higher $\mathrm{Nd}$ concentration and this suggests the threshold of allowed dopant concentration. There is yet any conclusive reason could be drawn for the improved electrical conductivity, 


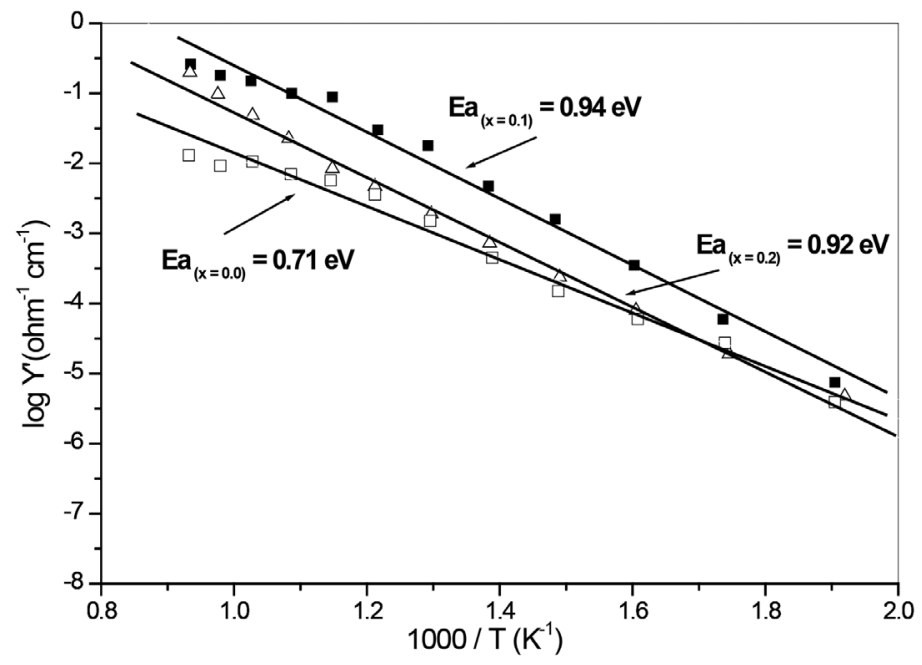

FIGURE 7. Arrhenius conductivity plots of $\mathrm{Bi}_{16} \mathrm{Y}_{04-\mathrm{x}} \mathrm{Nd}_{\mathrm{x}} \mathrm{O}_{3}$ solid solution $(0.00 \leq \mathrm{x} \leq 0.20)$

but it is probably a result of a more disordered and defective structure with high oxygen vacancy especially additional dopant is introduced.

\section{CONCLUSION}

Nd-substituted bismuth yttria fluorites, $\mathrm{Bi}_{16} \mathrm{Y}_{04-\mathrm{x}} \mathrm{Nd}_{\mathrm{x}} \mathrm{O}_{3}$ had been formed in a rather limited subsolidus solution, 0.00 $\leq \mathrm{x} \leq 0.20$. No significant cell expansion and only small variation of grain sizes were found for the doped samples. The temperature dependence of ac conductivity of the prepared samples was well postulated on Arrhenius-type conduction with their recorded activation energies in a range of $\sim 0.70-0.95 \mathrm{eV}$. High oxide ionic conductivity of the $\mathrm{Bi}_{1.6} \mathrm{Y}_{0.4-\mathrm{x}} \mathrm{Nd}_{\mathrm{x}} \mathrm{O}_{3}$ subsolidus solution was probably attributed to the defective structure of high oxygen vacancy that encouraged the hopping oxide ions over available vacant sites.

\section{ACKNOWLEDGEMENTS}

Special thanks to the financial support from the Ministry of Education, Malaysia via Fundamental Research Grant Scheme (FRGS).

\section{REFERENCES}

Boivin, J.C. 2001. Structural and electrochemical features of fast oxide ion conductors. International Journal of Inorganic Materials 3: 1261-1266.

Boivin, J.C. \& Mairesse, G. 1998. Recent material developments in fast ionic conductors. Chemistry of Materials 10: 28702888.

Harwig, H.A. \& Gerads, A.G. 1979. The polymorphism of bismuth sesquioxide. Thermochimica Acta 28: 121-131.

Harwig, H.A. \& Gerads, A.G. 1978. Electrical properties of $\alpha$, $\beta, \gamma$, and $\delta$ phases of bismuth sesquioxide. Journal of Solid State Chemistry 26: 265-274.

Irvine, J.T.S., Sinclair, D.C. \& West, A.R. 1990. Electroceramics: Characterization by impedance spectroscopy. Advanced Materials 2: 132-138.
Khaw, C.C., Tan, K.B. \& Lee, C.K. 2009. High temperature dielectric properties of cubic bismuth zinc tantalate. Ceramics International 35: 1473-1480.

Kruidhof, H., De Vries, K.J. \& Birggraaf, A.J. 1990. Thermochemical stability and nonstoichiometry of yttriastabilized bismuth oxide solid solutions. Solid State Ionics 37: 213-215.

Mairesse, G. 1993. In fast ion transport in solids, edited by Scrosati, B. Amsterdam: Kluver. p. 271.

Sammes, N.M., Tompsett, G.A., Nafe, H. \& Aldinger, F. 1999. Bismuth based oxide electrolytes-structure and ionic conductivity. Journal of the European Ceramic Society 19: 1801-1826.

Shannon, R.D. 1976. Revised effective ionic radii and systematic studies of interatomic distances in halides and chalcogenides. Acta Crystallography A 32: 751-767.

Stambouli, A.B. \& Traversa, E. 2002. Solid oxide fuel cells (SOFCs): A review of an environmentally clean and efficient source of energy. Renewable and Sustainable Energy Reviews 6: 433-455.

Sinclair, D.C. \& West, A.R. 1989. Impedance and modulus spectroscopy of semiconducting $\mathrm{BaTiO}_{3}$ showing positive temperature coefficient of resistance. Journal of Applied Physics 66: 3850-3856.

Takahashi, T. \& Iwahara, H. 1978. Oxide ion conductors based on bismuthsesquioxide. Materials Research Bulletin 13: 1447-1453.

Takahashi, T., Iwahara, H. \& Arao, T. 1975. High oxide ion conduction in sintered oxides of the system $\mathrm{Bi}_{2} \mathrm{O}_{3}-\mathrm{Y}_{2} \mathrm{O}_{3}$. Journal of Applied Electrochemistry 5: 187-195.

Tan, M.Y., Tan, K.B., Zainal,Z., Khaw, C.C. \& Chen, S.K. 2012. Subsolidus formation and impedance spectroscopy studies of materials in the $\left(\mathrm{Bi}_{2} \mathrm{O}_{3}\right)_{1-\mathrm{x}}\left(\mathrm{Y}_{2} \mathrm{O}_{3}\right)_{\mathrm{x}}$ binary system. Ceramics International 38: 3403-3409.

Watanabe, A. 1996. Phase equlibria in the system $\mathrm{Bi}_{2} \mathrm{O}_{3}-\mathrm{Y}_{2} \mathrm{O}_{3}$ : no possibility of $\delta-\mathrm{Bi}_{2} \mathrm{O}_{3}$ stabilization. Solid State Ionics 86-88: 1427-1430.

Watanabe, A. \& Kikuchi, T. 1986. Cubic hexagonal of yttriastabilized $\delta$-bismuth sesquioxide, $\mathrm{Bi}_{2-2 \mathrm{x}} \mathrm{Y}_{2 \mathrm{x}} \mathrm{O}_{3}(\mathrm{x}=0.215$ 0.235). Solid State Ionics 21: 287-291.

West, A.R. 1999. Crystal defects, non-stoichiometry and solid solutions. In Solid State Chemistry and It Applications. New York: John Wiley \& Sons, Ltd. pp. 226-240. 
Yashima, M. \& Ishimura, D. 2003. Crystal structure and disorder of the fast oxide ion conductor cubic $\mathrm{Bi}_{2} \mathrm{O}_{3}$, Chemical Physics Letter 378: 395-399.

N. Rahman, K.B. Tan, Z. Zainal \& M.P. Chon Department of Chemistry, Faculty of Science Universiti Putra Malaysia

43400 Serdang, Selangor Darul Ehsan

Malaysia

C.C. Khaw

Department of Mechanical and Material Engineering Faculty of Engineering and Science

Universiti Tunku Abdul Rahman

53300 Setapak, Kuala Lumpur

Malaysia
*Corresponding author; email: tankarban@upm.edu.my

Received: 13 August 2013

Accepted: 17 March 2015 